LITERATURE REVIEW

\title{
Management of immature necrotic permanent teeth with regenerative endodontic procedures - a review of literature
}

\author{
Muhammad Hasan Hameed, Meisha Gul, Robia Ghafoor, Sheikh Bilal Badar
}

\begin{abstract}
Immature necrotic permanent tooth presents a distinctive challenge for the endodontist. Various treatment modalities have been employed to create hard tissue barrier at the apex, which includes non-vital pulp therapy with calcium hydroxide, apexification with mineral trioxide aggregate, pulp revascularisation and regeneration. Regenerative endodontics is a novel modality which involves physiological replacement of the damaged structures of tooth like dentin, root and cells of the pulp-dentin complex. Numerous published case reports have revealed increased dentinal wall thickness, continued root development and apical closure, but there is still lack of sound scientific evidence regarding histological nature of the type of tissue. The current literature review was planned to summarise the evidence regarding the treatment of immature necrotic permanent teeth by regenerative endodontic procedures.
\end{abstract}

Keywords: Pluripotent stem cells, Mineral trioxide aggregate, Nonvital tooth, Platelet richplasma, Calcium hydroxide, Apexogenesis.

\section{doi:10.5455/JPMA.294366}

\section{Introduction}

Permanent immature teeth with necrotic pulp and periapical disease is a constant problem and area of keen interest for endodontists.1,2 Disinfection of root canal space is difficult to achieve in these teeth with endodontic files using standard protocol.1,2 Another difficulty arises during root canal filling due to lack of apical barrier in open apex and its impingement on periodontal tissues. 1,2 Even if these challenges are faced and sorted out, the roots of these teeth are very thin that constitute a high risk of fracture. ${ }^{3-5}$ Various treatment modalities have been described in literature to create hard tissue barrier at the apex, which includes non-vital pulp therapy with calcium hydroxide, apexification with mineral trioxide aggregate (MTA), pulp revascularisation and regeneration. 1,3,6

Aga Khan University Hospital, Karachi, Pakistan.

Correspondence: Muhammad Hasan Hameed.

Email: hasanhameed90@hotmail.com
The traditional non-vital pulp (NVP) therapy with calcium hydroxide $(\mathrm{Ca}(\mathrm{OH}) 2)$ has been studied largely and is reported to have a good outcome. ${ }^{7}$ However, there are certain limitations associated with this technique. ${ }^{5}$ The principal drawback is the long duration of about 6 and 18 months required for the formation of hard tissue apical barrier and required follow-ups every 3 months to check the progression of barrier formation.8,9 Patient compliance is extremely important for the completion of the procedure. This technique also tends to decrease the

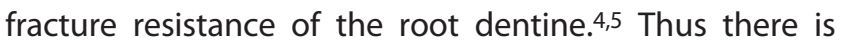
always a possibility of root fracture before hard tissue formation.2,10,11 Kahler et al. recently reported that tendency to root fracture is more related to the stage of root development rather than long-term $\mathrm{Ca}(\mathrm{OH}) 2$ use. $^{12}$ Apexification with MTA has also gained popularity among clinicians which is relatively easy and less time-consuming, but lack regenerative capability and long-term survival is also guarded due to reduced fracture resistance. ${ }^{13,14}$ Conventional root canal therapy (RCT) and apexification can only provide apical barrier, but possibility of reinfections and tooth fractures are very undesirable and disappointing for patients and practitioners. ${ }^{15}$

Recently, regenerative endodontics has gained significant interest in the field of endodontics. ${ }^{16}$ Considerable research towards successful regeneration of pulp-dentine complex (PDC) is progressing which emphasises on replacement of damaged structures such as dentine, PDC cells and root structures. ${ }^{17}$ Tissue regeneration and engineering is the most thought-provoking part of a tissue repair/regeneration programme because of pulp functional importance. ${ }^{18}$ The regenerated tissue should be vascularised, innervated and possess the ability to generate new odontoblasts which can produce new dentin matrices that later become mineralised. The concept of regeneration became popular when Banchs and Trope in 2004 treated immature necrotic and permanent teeth with new procedure and termed it 'revascularization'.19 Pulp revascularisation was an important step by the endodontic community on its path to exploring avenues of pulp and dentin regeneration. 20,21 
Table: Case series/reports published from 2004 till 2017.

\begin{tabular}{|c|c|c|c|c|c|c|}
\hline Author & $\begin{array}{l}\text { Sample } \\
\text { (Teeth) }\end{array}$ & $\begin{array}{l}\text { Intracanal } \\
\text { Medication }\end{array}$ & Scaffold & $\begin{array}{c}\text { Pulpal Space } \\
\text { Barrier/Restoration }\end{array}$ & Recall & Outcome \\
\hline Banchs \& Trope (2004) $)^{19}$ & 1 & Triple- antibiotics & Blood Clot & MTA/Resin & 2 years & Hard tissue barrier \\
\hline Chueh \& Huang (2006) 23 & 2 & Calcium hydroxide & None & Amalgam & 7 months to 5 years & Hard tissue barrier \\
\hline Shah et al.(2008) 24 & 14 & Formo-cresol & Blood Clot & Glass ionomer & 24 months & No hard tissue barrier \\
\hline Reynolds et al.(2009)25 & 2 & Triple-antibiotics & Blood Clot & MTA/composite & 18 months & No hard tissue barrier \\
\hline Thomson \& Kahler (2010)26 & 1 & Triple-antibiotics & Blood Clot & MTA/glass ionomer/composite & 18 months & No hard tissue barrier \\
\hline Petrino et al. $(2010)^{3}$ & 1 & Triple-antibiotics & Blood Clot & MTA/Resin & 08 months & Hard tissue barrier \\
\hline Torabinejad \&Turman, (2011)20 & 1 & Triple-antibiotics & PRP** & MTA*/Cavit/amalgam & $51 / 2$ month & Root Thickening/lengthening \\
\hline Iwaya et al.(2011)27 & 1 & Calcium hydroxide & None & GuttaPercha/ Composite resin & 30 months & Hard tissue barrier \\
\hline Dabbagh et al.(2012)28 & 18 & Triple antibiotics & Blood Clot & $\mathrm{MTA}^{*} /$ Resin & 24 months & Root lengthening and elongation \\
\hline Martin et al.(2013) 29 & 1 & Triple-antibiotics & PRP** & MTA/Resin & 12 months & Root Thickening/lengthening \\
\hline Nagata et al.(2014)30 & 23 & $\begin{array}{l}\text { Triple-Antibiotic/Calcium } \\
\text { hydroxide, chlorhexidine }\end{array}$ & Blood clot & $\begin{array}{c}\text { White MTA/ } \\
\text { Composite resin }\end{array}$ & 9-19 months & $\begin{array}{l}\text { Root Thickening/ } \\
\text { lengthening/apical closure }\end{array}$ \\
\hline Bezgin et al.(2015) $)^{31}$ & 2 & Triple-Antibiotic & PRP** & MTA & 12 months & Root Development/apical closure \\
\hline Bakhtiar et al.(2016) 33 & 4 & $\begin{array}{c}\text { Ciprofloxacin, Metronidazole } \\
\text { \& cefaclor }\end{array}$ & $\mathrm{PRF}^{* * *}$ & Bio-dentine & 12 months & $\begin{array}{c}\text { Root Development/ } \\
\text { apical closure }\end{array}$ \\
\hline $\begin{array}{l}\text { Timmerman }(2017)^{34} \\
\text { Closure }\end{array}$ & 1 & Calcium hydroxide & Blood clot & MTA*/Resin & 3 years & Root Development/apical \\
\hline
\end{tabular}

*MTA- Mineral trioxide aggregate

** PRP- Platelet rich plasma

***PRF- Platelet rich fibrin.

To treat immature necrotic teeth, we have to understand the pathogenesis and various factors that need to be considered before initiating treatment. Immature necrotic permanent tooth results in absence of Hertwig's epithelial root sheath and bacterial colonisation in pulp tissue. ${ }^{22}$ Factors that need to be considered include age of the patient, apical diameter, root canal disinfection, and antiseptic irrigants. Young patients have better prognosis due to strong immune defence mechanism and open apex allowing sufficient blood supply.

Multiple case reports/human studies on successful regenerative endodontic procedure have been conducted 19,23,34 (Table), but the current evidence regarding regenerated tissue and regenerative protocol still remains debatable.

The view of many authors regarding pulp regeneration is that it is not possible without revascularisation or angiogenesis and considered incomplete without the formation of an odontoblastic layer that lines the dentin surface. Pulp revascularisation only consists of reestablishment of vascularity in the pulp, but not necessarily the repopulation of odontoblasts that align on the dentin surfaces. Pulp regeneration is not completed without the development of nociceptive, sympathetic, parasympathetic nerve fibres and perhaps most importantly stem cells that aid in replacement of pulp cells in the regenerated pulp.

Thus, it can be concluded that pulp revascularisation is the induction of angiogenesis in an endodontically treated root canal, and pulp regeneration is pulp revascularisation plus the restoration of functional odontoblasts and/or nerve fibres. ${ }^{6}$

Case reports and case series have reported successful outcome of regenerative endodontic treatment in young immature necrotic teeth. $27,35,36$ The stage of root development also determines the most suitable treatment option. Teeth at stages 1,2 and $3(<$ half, $1 / 2,2 / 3$ root formation and open apex respectively) benefit from regenerative endodntic treatment, but teeth at stage 4 (almost complete root formation) can be treated by both regenerative endodontics and MTA apical plug. ${ }^{37}$ Teeth with $0.5 \mathrm{~mm}$ to $1 \mathrm{~mm}$ apical diameter has the highest success rate. ${ }^{38}$ Persistent infection damages the stem cells and halts the process of repair and regeneration, therefore complete disinfection is important for pulp tissue regeneration. ${ }^{39}$ Root canal disinfection can be effectively achieved using passive and active ultrasonic irrigation, and negative pressure irrigation. 39

It has been reported that triple antibiotic paste and concentrated hypocholite result in stem cell damage and ultimately regeneration. ${ }^{40-43}$ Besides these, extent of 
apical periodontitis, trauma, compliance, patient age and stage of root development also affect the process of regenerative endodontics. ${ }^{44,45}$ Regenerative endodontics takes into account the principles of tissue engineering and regenerative medicine which require correct threedimensional (3D) assembly of dental stem cells, 3D scaffolds and growth factors to form a functional and useful PDC. ${ }^{18,46}$

\section{Dental Stem Cells}

The stem cell has the ability of continuous division and production of progeny cells that can differentiate into numerous other cell and tissue types. ${ }^{17}$ They are either foetal / embryonic or postnatal/adult. ${ }^{15}$ Stem cells are classified into totipotent, pluripotent and multi-potent. 47 Pluripotent stemcells have the ability to become specialiszed cells from all three germ layers, whereas multi-potent cells differentiate only into specialised cells of the tissue of origin. 47 To regenerate a tissue, the best stem cells are embryonic stem cells, but their source is controversial and can raise ethical issues. ${ }^{47}$

Postnatal stem cell sources include variety of human tissues including oro-facial tissues. ${ }^{18}$ An important requirement for regeneration of pulp tissues is to obtain stem cells that can differentiate into odontoblasts. ${ }^{18}$ All stem cells involved in odontogenesis are ectomesenchymal in origin with the exception of ameloblast progenitor cells. ${ }^{18}$ Postnatal mesenchymal stem cells can be classified as stem cells derived from dental tissues (dental pulp, periodontal ligament etc.) and extra-dental sources (bone). ${ }^{18}$

Five types of postnatal mesenchymal stem cells have the reported ability of differentiation into odontoblast-like cells which include stem cells of human exfoliated deciduous teeth (SHED), dental pulp stem cells (DPSC), stem cells of the apical papilla (SCAP), bone marrowderived mesenchymal stem cells (BMMSC) and dental follicle progenitor cells (DFPC). ${ }^{48-53}$

\section{Scaffold}

Scaffold is a 3D structure used in many tissue-engineering applications. When scaffold is seeded with stem cells, they can proliferate and differentiate into new tissues that ultimately replace the scaffold. 54,55 Ideal scaffold must be bio-compatible, sterilisable, non-cytotoxic, should not evoke any inflammatory response, remain stable, and provide cellular support and vascularisation. It should have an inductive ability with added growth factors and morphogens for a more rapid cellular attachment, proliferation, migration and differentiation into a specific tissue. 55
Currently many regenerative endodontic procedures (REPs) have made use of dentine and the autologous platelet concentrates (blood clot [platelet-rich fibrinPRF]or platelet-rich plasma [PRP]) to serve as scaffold.20,56,57 They are believed to induce stem cell proliferation and differentiation from the apical papilla or other pulp cells because of the presence of growth factors. ${ }^{8}$ However, many animal studies have highlighted a common feature that the new pulp-like tissue after revascularisation using either PRP alone or in conjunction with pulp stem cells was devoid of odontoblastic cell layer so this tissue could not be considered true pulp. ${ }^{59}$ Similar findings emerged from other pre-clinical studies in which odontoblasts were not identified, even if many pulp tissue elements were histologically detected as fibroblasts, blood vessels and collagen. 59

Massimo et al. in a systematic review concluded that there is no current protocol to achieve a true regeneration of the necrotic pulp tissue using autologous platelet concentrates either in immature or mature teeth and the benefit of the use of PRP to achieve predictable regeneration of the pulp is still unclear. ${ }^{57}$

\section{Growth Factors}

Growth factors are the proteins which bind to receptors on the target cell and act as signals that modulate cell behaviour by inducing cellular proliferation and/or differentiation, chemotaxis, angiogenesis and neuronal growth. Growth factors recruit stem/progenitor cells from their perivascular or other niches to replace the damaged cells by differentiating into a specific cell phenotype and proliferation in the area of injury. ${ }^{17,60}$ Key growth factors in pulp and dentin formation include transforming growth factor-beta, bone morphogenetic protein and fibroblastic growth factor. Recent REPs focus on utilisation of growth factors derived from dentine and platelets. ${ }^{20}$ Studies have reported that dentin can be considered a reservoir of growth factors and other bioactive molecules that, when released, play significant role in repair and regenerative procedures. ${ }^{61-63}$

Smith et al. reported that there are various bioactive molecules, including cytokines, growth factors and matrix molecules, that are present in dentin and pulp which are believed to promote reparative and regenerative events after injury. ${ }^{62}$ Bioactive molecules released by the various tissue preparation agents, irrigants like Ethylenediaminetetraacetic acid (EDTA), medicaments and materials commonly used in endodontics influences regenerative events, including chemotaxis, differentiation of odontoblasts, mineralisation, angiogenesis and neurogenesis. 54 Thus, endogenous bioactive molecules 


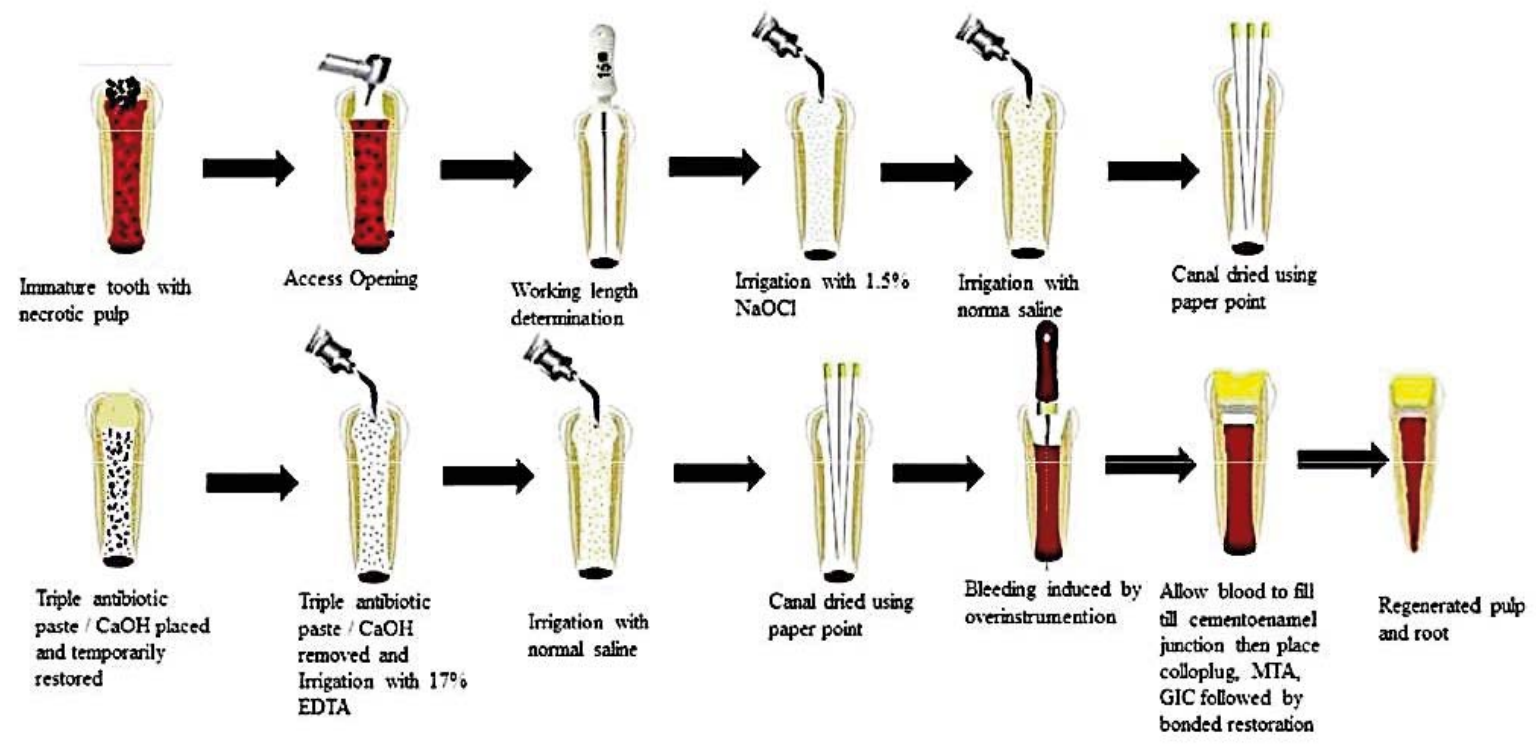

Figure: Protocol of Regenerative Endodontics.

can be targeted to promote regeneration only if the canals are adequately disinfected, which is a pre-requisite for regeneration/repair.

The recommended protocol by the American Association of Endodontics (AAE) (Figure) for regenerative endodontics require initial passive irrigation with $1.5 \%$ sodium hypochlorite ( $\mathrm{NaOCl}) .3,19,64-66$ Various concentrations of $\mathrm{NaOCl}$ has been reported in literature such as $1.25 \%, 5 \%, 5.25 \%$ and $6 \%$ and $2 \%$ and $0.12 \%$ concentration of chlorhexidine.1,3,19,65,67-70 At first appointment, slow irrigation with $1.5 \% \mathrm{NaOCl}$ and then saline, placing the irrigating needle at a distance of $1 \mathrm{~mm}$ from the apex followed by dressing with triple antibiotic paste (TAP) (ciprofloxacin + metronidazole + minocycline) ensuring that it remains below the cementoenamel junction (CEJ) so as to minimise the risk of staining. ${ }^{66,71} \mathrm{At}$ second appointment, removal of this paste is done only after resolution of signs and symptoms clinically, bleeding is induced in the canals afterwards using sterile file by over-instrumentation followed by placement of CollaPlug/CollaCote barrier at the orifice. Final step is sealing of canal orifice using MTA followed by permanent restoration with crown. 3,19,71 Follow-up is generally done after 3 months clinically and radiographically to check for resolution of signs and symptoms and increase in length and thickness of the root usually after 12-24 months post treatment.

\section{Limitations of Regenerative Endodontics}

Although regenerative endodontics is a great modality to manage immature necrotic teeth, there are limitations to REPs, which include the risk of dental crown-staining induced by materials like TAP/ minocycline and MTA. Clinicians are required to have adequate knowledge to deal with these technical challenges. Use of epinephrinecontaining local anaesthetics is a well-known cause of insufficient bleeding; this can be dealt with by using mepivacaine (3\%) as an alternative during the second visit before lacerating the apical papilla. However, Hertwig's epithelial root sheath must be protected by avoiding extension of instrument laterally or circumferentially because it directs the shape and continued development of root. ${ }^{72}$

Another common complication that arises is inadvertent staining of the tooth due to exposure to minocycline or TAP used as intra-canal medication. Various strategies have been advised to prevent staining which include sealing of dentinal tubules by bonding agents, use of double antibiotic paste eliminating minocycline or $\mathrm{Ca}(\mathrm{OH}) 2$ use..$^{71-73}$ Use of MTA and other barrier materials are also believed to cause staining, especially when placed above the CEJ.74 Replacing minocycline by other antibiotic as cefaclor or amoxicillin is another strategy to avoid discolouration. Staining can be prevented by placing the MTA below the CEJ or in the middle third of the canal, use of other biomaterial which has inherent bioactive property like Biodentine, while another approach favours the use of CollaPlug (Zimmer Dental Inc., Warsaw, IN) over the blood clot.3,33,75 
One major limitation of REP is the lack of the viability of stem cells of apical papilla (SCAP). Pre-existing periapical lesions can damage SCAP, and, similarly, use of NaOClandintra-canal medication at high concentration can also impair SCAP. The in-growth of periodontal tissues (i.e: cementum, periodontal ligament, and bone) into the root canal are believed to be the major reasons for repair instead of regeneration. ${ }^{76}$ Unpredictable root maturation is a concern reported in studies. ${ }^{77,78}$ but studies have also reported resolution of periapical periodontits in $91 \%$ cases, apical closure in $80 \%$ and root development in $80 \%$ cases. ${ }^{20,73}$

\section{Conclusion}

Although the current research in regenerative therapy is very promising, complete biological regeneration of periodontal and endodontic tissues is not yet predictably obtained because of the histological nature of the regenerated tissue which suggests that REPs promote guided-endodontic repair (GER) instead of 'true regeneration' of a PDC. The development of regenerative endodontics may eliminate the need for more complex procedures, like extraction and implant replacement. Further research and randomised clinical trials (RCTs) are needed to develop strong scientific evidence regarding this procedure.

\section{Disclaimer: None.}

\section{Conflict of Interest: None.}

\section{Source of Funding: None.}

\section{References}

1. Chueh LH, Ho YC, Kuo TC, Lai WH, Chen YHM, Chiang CP. Regenerative endodontic treatment for necrotic immature permanent teeth. J Endod. 2009; 35:160-4.

2. Trope M. Treatment of the immature tooth with a non-vital pulp and apical periodontitis. Dent Clin North Am. 2010; 54:313-24.

3. Petrino JA, Boda KK, Shambarger S, Bowles WR, McClanahan SB. Challenges in regenerative endodontics: a case series. J Endod. 2010; 36:536-41.

4. Andreasen JO, Farik B, Munksgaard EC. Long-term calcium hydroxide as a root canal dressing may increase risk of root fracture. Dent Traumatol. 2002; 18:134-7.

5. Doyon GE, Dumsha T, von Fraunhofer JA. Fracture resistance of human root dentin exposed to intracanal calcium hydroxide. J Endod. 2005; 31:895-7.

6. Mao JJ, Kim SG, Zhou J, Ye L, Cho S, Suzuki T, et al. Regenerative endodontics: barriers and strategies for clinical translation. Dent Clin North Am. 2012; 56:639-49.

7. Al Ansary MA, Day PF, Duggal MS, Brunton PA. Interventions for treating traumatized necrotic immature permanent anterior teeth: inducing a calcific barrier \& root strengthening. Dent Traumatol. 2009; 25:367-79.

8. Nosrat A, Homayounfar N, Oloomi K. Drawbacks and unfavourable outcomes of regenerative endodontic treatments of necrotic immature teeth: a literature review and report of a case. J Endod. 2012; 38:1428-34.
9. Cehreli ZC, Isbitiren B, Sara S, Erbas G. Regenerative endodontic treatment (revascularization) of immature necrotic molars medicated with calcium hydroxide: a case series. J Endod. 2011; 37:1327-30.

10. Kerekes K, Heide S, Jacobsen I. Follow-up examination of endodontic treatment in traumatized juvenile incisors. J Endod. $1980 ; 6: 744-8$.

11. Frank AL. Therapy for the divergent pulpless tooth by continued apical formation. J Am Dent Assoc. 1966; 72:87-93.

12. Kahler SL, Shetty S, Andreasen FM, Kahler B. The effect of longterm dressing with calcium hydroxide on the fracture susceptibility of teeth. J Endod. 2018; 44:464-9.

13. Mente J, Hage N, Pfefferle T, Koch MJ, Dreyhaupt J, Staehle HJ, et al. Mineral trioxide aggregate apical plugs in teeth with open apical foramina: a retrospective analysis of treatment outcome. J Endod. 2009; 35:1354-8.

14. Witherspoon DE, Small JC, Regan JD, Nunn M. Retrospective analysis of open apex teeth obturated with mineral trioxide aggregate. J Endod. 2008; 34:1171-6.

15. Yang M. Regenerative endodontics: a new treatment modality for pulp regeneration. JSM Dent. 2013; 1:10-11.

16. Smith AJ, Cooper PR. Regenerative Endodontics: Burning Questions. J Endod. 2017 1;43:S1-6.

17. Kim SG, Zhou J, Solomon C, Zheng Y, Suzuki T, Chen M, et al. Effects of growth factors on dental stem/progenitor cells. Dent Clin North Am. 2012; 56:563-75.

18. Goodis HE, Kinaia BM, Kinaia AM, Chogle SM. Regenerative endodontics and tissue engineering: what the future holds? Dent Clin North Am. 2012; 56:677-89.

19. Banchs F, Trope M. Revascularization of immature permanent teeth with apical periodontitis: new treatment protocol? J Endod. 2004; 30:196-200.

20. Torabinejad M, Turman M. Revitalization of tooth with necrotic pulp and open apex by using platelet-rich plasma: a case report. J Endod. 2011; 37:265-8.

21. Hargreaves KM, Giesler T, Henry M, Wang $Y$. Regeneration potential of the young permanent tooth: what does the future hold? J Endod. 2008; 34:S51-6.

22. Ricucci D, Siqueira Jr JF, Loghin S, Lin LM. Pulp and apical tissue response to deep caries in immature teeth: A histologic and histobacteriologic study. J Dent. 2017;56:19-32.

23. Chueh LH, Huang GT. Immature teeth with periradicular periodontitis or abscess undergoing apexogenesis: a paradigm shift. J Endod. 2006; 32:1205-13.

24. Shah N, Logani A, Bhaskar U, Aggarwal V. Efficacy of revascularization to induce apexification/apexogensis in infected, nonvital, immature teeth: a pilot clinical study. J Endod. 2008; 34: 919-25.

25. Reynolds K, Johnson JD, Cohenca N. Pulp revascularization of necrotic bilateral bicuspids using a modified novel technique to eliminate potential coronal discolouration: a case report. IntEndod J. 2009: 42: 84-92.

26. Thomson A, Kahler B. Regenerative endodontics biologicallybased treatment for immature permanent teeth: a case report and review of the literature. Aust Dent J. 2010: 55: 446-52.

27. Iwaya S, Ikawa M, Kubota M. Revascularization of an immature permanent tooth with periradicular abscess after luxation. Dent Traumatol. 2011: 27: 55-8.

28. Dabbagh B, Alvaro E, Vu DD, Rizkallah J, Schwartz S. Clinical complications in the revascularization of immature necrotic permanent teeth. Pediatr Dent. 2012; 34:414-7.

29. Martin G, Ricucci D, Gibbs JL, Lin LM. Histological findings of revascularized/revitalized immature permanent molar with apical periodontitis using platelet-rich plasma. J Endod 2013: 39: 13844. 
30. Nagata JY, de Almeida Gomes BP, Lima TF, Murakami LS, de Faria DE, Campos GR, et al. Traumatized immature teeth treated with 2 protocols of pulp revascularization. J Endod. 2014; 40:606-12.

31. Bezgin T, Yilmaz AD, Celik BN, Kolsuz ME, Sonmez H. Efficacy of platelet-rich plasma as a scaffold in regenerative endodontic treatment. J Endod. 2015; 41:36-44.

32. Nosrat A, Kolahdouzan A, Hosseini F, Mehrizi EA, Verma P, Torabinejad $M$. Histologic outcomes of uninfected human immature teeth treated with regenerative endodontics: 2 case reports. J Endod. 2015; 41:1725-9.

33. Bakhtiar $\mathrm{H}$, Mirzaei $\mathrm{H}$, Bagheri MR, Fani $\mathrm{N}$, Mashhadiabbas $\mathrm{F}$, Eslaminejad $M B$, et al. Histologic tissue response to furcation perforation repair using mineral trioxide aggregate or dental pulp stem cells loaded onto treated dentin matrix or tricalcium phosphate. Clin Oral Investig. 2017; 21:1579-88.

34. Timmerman A, Parashos P. Delayed Root Development by Displaced Mineral Trioxide Aggregate after Regenerative Endodontics: A Case Report. J Endod. 2017; 43:252-6.

35. Chen YP, Jovani-Sancho MD, Sheth CC. Is revascularization of immature permanent teeth an effective and reproducible technique? Dent Traumatol. 2015; 31:429-36.

36. Tsukiboshi M, Ricucci D, Siqueira Jr JF. Mandibular Premolars with Immature Roots and Apical Periodontitis Lesions Treated with Pulpotomy: Report of 3 Cases. J Endod. 2017; 43:S65-74.

37. Cvek M. Prognosis of luxated non-vital maxillary incisors treated with calcium hydroxide and filled with gutta-percha. A retrospective clinical study. Dent Traumatol. 1992;8:45-55.

38. Fang Y, Wang X, Zhu J, Su C, Yang Y, Meng L. Influence of Apical Diameter on the Outcome of Regenerative Endodontic Treatment in Teeth with Pulp Necrosis: A Review. J Endod. 2018; 44:414-31.

39. Fouad AF. Microbial Factors and Antimicrobial Strategies in Dental Pulp Regeneration. J Endod. 2017; 43:S46-S50.

40. Trevino EG, Patwardhan AN, Henry MA, Perry G, DybdalHargreaves $N$, Hargreaves KM, et al. Effect of irrigants on the survival of human stem cells of the apical papilla in a platelet-rich plasma scaffold in human root tips. J Endod. 2011 1; 37:1109-15.

41. Martin DE, De Almeida JF, Henry MA, Khaing ZZ, Schmidt CE, Teixeira FB, et al. Concentration-dependent effect of sodium hypochlorite on stem cells of apical papilla survival and differentiation. J Endod. 2014; 40:51-5.

42. Althumairy R, Hargreaves $K$, Teixeira F, Henry M, Diogenes A. the Effect of Dentin Conditioning With Medicaments Used in Regenerative Procedures on the Survival of Scap: or 57. J Endod. 2013; 39:e15.

43. Ruparel NB, Teixeira FB, Ferraz CC, Diogenes A. Direct effect of intracanal medicaments on survival of stem cells of the apical papilla. J Endod. 2012; 38:1372-5.

44. Saoud TM, Zaazou A, Nabil A, Moussa S, Lin LM, Gibbs JL. Clinical and radiographic outcomes of traumatized immature permanent necrotic teeth after revascularization/revitalization therapy. J Endod. 2014; 40:1946-52.

45. Lin J, Zeng Q, Wei X, Zhao W, Cui M, Gu J, et al. Regenerative endodontics versus apexification in immature permanent teeth with apical periodontitis: a prospective randomized controlled study. J Endod. 2017; 43:1821-7.

46. Geisler TM. Clinical considerations for regenerative endodontic procedures. Dent Clin North Am. 2012; 56:603-26.

47. Zare S, Kurd S, Rostamzadeh A, Nilforoushzadeh MA. Types of Stem Cells in Regenerative Medicine: A Review. J Skin Stem Cell. 2014; $1: \mathrm{e} 28471$.

48. Gronthos S, Brahim J, Li W, Fisher LW, Cherman N, Boyde A, et al. Stem cell properties of human dental pulp stem cells. J Dent Res. 2002; 81:531-5.

49. Ji YM, Jeon SH, Park JY, Chung JH, Choung YH, Choung PH. Dental stem cell therapy with calcium hydroxide in dental pulp capping.
Tissue Eng Part A. 2010; 16:1823-33.

50. Miura M, Gronthos S, Zhao M, Lu B, Fisher LW, Robey PG, et al. SHED: stem cells from human exfoliated deciduous teeth. Proc Natl Acad Sci U S A. 2003; 100:5807-12.

51. Mrozik KM, Zilm PS, Bagley CJ, Hack S, Hoffmann P, Gronthos S, et al. Proteomic characterization of mesenchymal stem cell-like populations derived from ovine periodontal ligament, dental pulp, and bone marrow: analysis of differentially expressed proteins. Stem Cells Dev. 2010; 19:1485-99.

52. Peng L, Ye L, Zhou XD. Mesenchymal stem cells and tooth engineering. Int J Oral Sci. 2009; 1:6-12.

53. Estrela C, Alencar AH, Kitten GT, Vencio EF, Gava E. Mesenchymal stem cells in the dental tissues: perspectives for tissue regeneration. Braz Dent J. 2011; 22:91-8.

54. Galler KM, D'Souza RN, Federlin M, Cavender AC, Hartgerink JD, Hecker S, et al. Dentin conditioning codetermines cell fate in regenerative endodontics. J Endod. 2011; 37:1536-41.

55. Yuan Z, Nie H, Wang S, Lee CH, Li A, Fu SY, et al. Biomaterial selection for tooth regeneration. Tissue Eng Part B, Reviews. 2011; 17:373-88.

56. Jansen JA. The performance of dental pulp stem cells on nanofibrous $\mathrm{PCL} /$ gelatin/nHA scaffolds. J Biomed Mater Res A. 2010; 93:247-57.

57. Del Fabbro M, Bortolin M, Taschieri S, Weinstein R. Is platelet concentrate advantageous for the surgical treatment of periodontal diseases? A systematic review and meta-analysis. J Periodontol. 2011; 82:1100-11.

58. Anitua E, Andia I, Ardanza B, Nurden P, Nurden AT. Autologous platelets as a source of proteins for healing and tissue regeneration. Thromb Haemost. 2004; 91:4-15.

59. Zhang DD, Chen X, Bao ZF, Chen M, Ding ZJ, Zhong M. Histologic comparison between platelet-rich plasma and blood clot in regenerative endodontic treatment: an animal study. J Endod. 2014; 40:1388-93.

60. Huang GT, Yamaza T, Shea LD, Djouad F, Kuhn NZ, Tuan RS, et al. Stem/progenitor cell-mediated de novo regeneration of dental pulp with newly deposited continuous layer of dentin in an in vivo model. Tissue Eng Part A. 2010; 16:605-15.

61. Begue-Kirn C, Smith AJ, Ruch JV, Wozney JM, Purchio A, Hartmann $D$, et al. Effects of dentin proteins, transforming growth factor beta 1 (TGF beta 1) and bone morphogenetic protein 2 (BMP2) on the differentiation of odontoblast in vitro. Int J Dev Biol. 1992; 36:491-503.

62. Smith $\mathrm{AJ}$, Lesot $\mathrm{H}$. Induction and regulation of crown dentinogenesis: embryonic events as a template for dental tissue repair? Crit Rev Oral Biol Med. 2001; 12:425-37.

63. Thesleff I, Vaahtokari A, Partanen AM. Regulation of organogenesis: common molecular mechanisms regulating the development of teeth and other organs. Int J Dev Biol. 1995; 39:35-50.

64. American Association of Endodontics. AAE Clinical Considerations for a Regenerative Procedure [Internet]. American Association of Endodontics. 2016. [Online] [Cited 2018 February 15]. Available from:

URL: https://www.aae.org/specialty/wpcontent/uploads/sites/2/2017/ 06/currentregenerativeendodonticconsiderations.pdf.

65. Ding R, Cheung G, Chen J, Yin X, Wang Q, Zhang C. Pulp revascularization of immature teeth with apical periodontitis: a clinical study. J Endod 2009; 35:745-9.

66. Hoshino E, Kurihara-Ando N, Sato I, Uematsu H, Sato M, Kota K, et al. In-vitro antibacterial susceptibility of bacteria taken from infected root dentine to a mixture of ciprofloxacin, metronidazole and minocycline. Int Endod J. 1996; 29:125-30

67. Trevino EG, Patwardhan AN, Henry MA, Perry G, DybdalHargreaves $N$, Hargreaves $\mathrm{KM}$, et al. Effect of irrigants on the 
survival of human stem cells of the apical papilla in a platelet-rich plasma scaffold in human root tips. J Endod. 2011; 37:1109-15.

68. Basrani BR, Manek S, Sodhi RN, Fillery E, Manzur A. Interaction between sodium hypochlorite and chlorhexidinegluconate. J Endod. 2007; 33:966-9.

69. Cotti E, Mereu M, Lusso D. Regenerative treatment of an immature, traumatized tooth with apical periodontitis: report of a case. J Endod. 2008; 34:611-6.

70. Shin S, Albert J, Mortman R. One step pulp revascularization treatment of an immature permanent tooth with chronic apical abscess: a case report. Int Endod J. 2009; 42:1118-26.

71. KimJ, KimY, Shin S, Park J, Jung I. Tooth discoloration of immature permanent incisor associated with triple antibiotic therapy: a case report. J Endod. 2010; 36:1086-91.

72. Diogenes A, Henry MA, Teixeira FB, Hargreaves KM. An update on clinical regenerative endodontics. Endod Top. 2013; 28:2-23.

73. Thibodeau B, Trope $M$. Pulp revascularization of a necrotic infected immature permanent tooth: case report and review of the literature. Pediatr Dent. 2007: 29: 47-50.
74. Lenherr P, Allgayer N, Weiger R, Filippi A, Attin T, Krastl G. Tooth discoloration induced by endodontic materials: a laboratory study. Int Endod J. 2012: 45: 942-49.

75. Jeeruphan T, Jantarat J, Yanpiset K, Suwannapan L, Khewsawai $P$, Hargreaves KM. Mahidol study 1: Comparison of radiographic and survival outcomes of immature teeth treated with either regenerative endodontic or apexification methods: a retrospective study. J Endod 2012: 38:1330-6.

76. Diogenes A, Ruparel NB. Regenerative endodontic procedures: clinical outcomes. Dent Clin North Am. 2017; 61:111-25.

77. Linsuwanont $P$, Sinpitaksakul $P$, Lertsakchai T. Evaluation of root maturation after revitalization in immature permanent teeth with nonvital pulps by cone beam computed tomography and conventional radiographs. Int Endod J. 2017; 50:836-46.

78. Tong HJ, Rajan S, Bhujel N, Kang J, Duggal M, Nazzal H. Regenerative Endodontic Therapy in the Management of Nonvital Immature Permanent Teeth: A Systematic Review-Outcome Evaluation and Meta-analysis. J Endod. 2017; 43:1453-64 